\title{
NOTAS SOBRE LA OBRA CIENTÍFICA DE COSERIU (4)
}

\author{
José Polo \\ (Universidad Autónoma de Madrid)
}

II

ARQUITECTURA DE LA LENGUA

2: paréntesis que desembocará en Coseriu (2)

B

testimonios complementarios

0

En la entrega anterior presenté información y textos «antiguos»: hasta el siglo XIX inclusive. Cabría ahora entrar ya en el s. xx, pero mostraré todavía algunos materiales anteriores al siglo en que vivimos como ejemplo último sintomático de lo mucho que podríamos recoger, en torno a los ejes diastrático y diafásico, en épocas alejadas de la nuestra. Quiero hacer notar que, en las realidades que ocupan nuestra atención -atinentes, como digo, sobre todo, a los dialectos verticales y a los estilísticos- $\tan$ importante es la aprehensión de la doctrina como la propia terminología: no hay, pues, que establecer ruptura en la línea de «lo profundo/lo superficial», sino examinar las formas mil (con estructuras sintácticas, mediante voces más bien cercanas al lenguaje común, con léxico especializado, etc.) como aparecen y desaparecen dichas realidades conceptuales a través del tiempo. Si una terminología es «responsable», forzosamente aportará algún resquicio de avance en la doctrina, algún paso en la superación de lo dado. En fin, téngase en cuenta, concluyo, que los materiales que voy presentando en este «paréntesis» tienen una ıneta muy clara: crear el contexto adecuado para, en su momento, situar el aporte de Coseriu, en lo relacionado ahora con «arquitectura de la lengua», en el marco del desarrollo de la lingüística, especialmente en su proyección hispánica. 


\section{La Editorial Gredos (Madrid)}

0

Me refiero, claro está, a su contribución al conocimiento de las ideas en el tema que nos ocupa. En todas las obras que voy a mencionar hay riqueza de doctrina sobre la cuestión de los niveles y estilos de lenguaje, más hacia lo uno o lo otro según a qué estudio o ensayo nos dirijamos. Repito que no se trata de presentar a los clásicos greco-latinos, etc., sino de llamar la atención, a manera de espécimen, sobre algunas de las zonas o de los autores que cabría explorar si deseáramos ir más allá de un «aperitivo» en esta materia. Entremos ya en el terreno de las fichas...

A

1. Poética de Aristóteles, edición trilingüe de Valentín García Yebra, Gredos (Biblioteca Románica Hispánica), 1974.

B

2. Aristóteles, Retórica, número 142 de Biblioteca Clásica Gredos, 1990 (introducción, traducción y notas de Quintín Racionero; revisión: Carlos García Gual).

3. Teón, Hermógenes, Aftono, Ejercicios de retórica, núm. 158, 1991 (introducción, traducción y notas de $\mathbf{M}^{\mathrm{a}}$. Dolores Reche Martínez; revisión: Felipe Hernández Muñoz).

4. Hermógenes, Sobre las formas de estilo, núm. 184, 1993 (introducción, traducción y notas de Consuelo Ruiz Montero; revisión: José Mà . Rodríguez Jiménez).

C

5. LUZÁN, Ignacio, Arte de hablar, o sea, retórica de las conversaciones [1729], Biblioteca Románica Hispánica, 1991 (edición, introducción y notas de Manuel Béjar Hurtado). Aunque no dé aquí la ficha completa por ceñirme a una sola editorial, téngase muy en cuenta su «obra gemela», La poética [...] (1737 y 1789; véase la edición de Isabel Cid de Sirga — Cátedra, Madrid, 1974-y, sobre todo, la de Russell P. Sebold: Labor, Barcelona, 1977).

\section{Más sobre el Renacimiento}

En opúsculo reciente (Ediciones del Colegio de España, Salamanca, 1993), Juan Clemente Zamora MunNÉ dedica un capítulo, págs. 51-60, al asunto del que nos 
ocupamos: «Los conceptos de dialecto y sociolecto en el Renacimiento español». Independientemente de la extensión del tratamiento y de las ideas vertidas, resulta muy positivo el deseo de conocimiento «sociolingüístico» de una época tan fecunda en doctrina sobre el lenguaje, como puede observarse, por ejemplo, en el instructivo volumen de Juan M. Lope Blanch (Arco-Libros, Madrid, 1990), mencionado en la entrega anterior, $A$-2. En la segunda ficha que presente podremos observar alguna de las ideas del prof. Zamora Munné. Conozcamos ahora los datos de una obra, a su vez, rica en enseñanzas prácticas...

1. Torquemada, Antonio de, Manual de escribientes [prob. 1552], anejo xxi del $B R A E$, Madrid, 1970; edición de Mª . Josefa C. de Zamora y Alonso Zamora Vicente. Para nuestro propósito, interesa todo el texto (págs. 59-261), espec. «De las consideraçiones q[ue] han de hazer los que escriuieren alguna carta para no errar en lo que dixieren» (págs. 176-183; con los siguientes epígrafes: Quién, A quién; Quándo; De qué manera); "Qué manera de escreuir sea mejor para vsarse en las cartas» (págs. 184-188); «Qué cosa es estilo y quántas maneras de estilos ay en el escreuir» (págs. 188-194; con los siguientes epígrafes: Estilo subido; Estilo graue; Del estilo delicado; Estilo elegante; Estilo gracioso; Estilo llano; Estilo torpe); «De la conformidad y mezcla de los estilos» (pág. 195); «Del estilo que han de seguir los secretarios» (págs. 196-197); «De los géneros y diferençias de cartas» (págs. 197-198); «De cómo es lícita la ynmitaçión a los que escriuen cartas» (págs. 198-200); «De las significaçiones de este nonbre, título y de los títulos de cartas que se vsan en la lengua castellana» (págs. 200-209; tras una introducción, dos apartados: Los títulos eclesiásticos; De los títulos seglares). En realidad,cabría seguir mencionando «capítulos» de interés, pues todo lo que viene después posee relación directa con nuestrocentro de investigación; cartas de «visitaçión», de «cunplimientos», «en que se da la enorabuena», de "consuelo», de «fauor», de «negoçios», de «agrauio», de «agradeçimiento», «de las rrespuestas de las cartas», «del çerrar de las ca[rta]s», etc.

2. Atrás, 0 , he mencionado el hecho de la atención prestada por el prof. Zamora Munné a las inquietudes de «arquitectura del lenguaje» de nuestros humanistas del Renacimiento. En su repaso nos presenta a Antonio de Nebrija, Juan de Valdés, Bernardo José de Aldrete (del que muestra un texto «que anticipa el concepto de idiolecto, la manera de hablar que caracteriza no al grupo sino al individuo» y que reconoce además la variedad «no sólo entre regiones sino también entre el habla urbana y la rural, y aun dentro de cada una de éstâs»). También se fija en Sebastián de Covarrubias y, naturalmente, en Gonzalo Correas: «Pero lo más interesante es que Correas percibe perfectamente la variedad diastrática, sociolectal, describiendo explícitamente la complejidad social de una lengua» (pág. 58; cita luego parte del texto que yo reproduje - véase la entrega anterior, $A-2$ - a través del estudio del prof. Lope Blanch como primera pista). Continúa en la misma página: «Además se 
da cuenta que esta variedad sociolectal tiene una función, y que cada variante es igualmente válida y se justifica dentro de su contexto social» (reproduce otro fragmento del texto conjunto acabado de aludir). Ahora (págs. 58-59):

Nada de lo anterior permite, desde luego, pretender retrotraer al Renacimiento la génesis de la dialectología o de la sociolingüística como ciencias. No se las estudia como tales, ni para ellas se tienen las correspondientes metodologías. Sin embargo, como se ha visto, desde principios del siglo XVI, a partir de Valdés, se discuten en España hechos y conceptos dialectales y sociolectales [sintetiza a continuación los aportes de Valdés y Aldrete; luego añade...]. Dispersos en los textos de la época se encuentran ejemplos que demuestran que se reconoce el carácter diastrático de la variación.

3. Y de nuevo sobre el autor que más nos interesa, anota el prof. Zamora Munné (pág. 59):

La obra de Gonzalo Correas es particularmente digna de mención, en ésta como en otras materias, porque no sólo reconoce la variación fónica y léxica, sino que nos da también muestras de variación morfosintáctica. Pero lo que la hace aun más moderna es su percepción, muy bien y explícitamente señalada, de la variación que se produce por lo que hoy llamaríamos factores sociolingüísticos: edad, sexo, educación, ocupación y nivel o jerarquía social. Muy acorde con criterios actuales igualmente es afirmar, como lo hace Correas, que la lengua es válida en todos sus niveles, según el contex to y por quien [mejor lectura: quién] se use.

4. Acaba este investigador el mencionado capítulo con las siguientes palabras (pág. 59):

Todo lo anterior permite concluir que los filólogos y gramáticos españoles del siglo xvi y principios del XvI analizan y perciben las cuestiones dialectales y sociolectales con extraordinaria claridad para la época. Anticipan inclusive algunos conceptos que no se volverán a formular tan precisamente hasta la segunda mitad de nuestro siglo [afirmación quizá algo rotunda: compárese, en la entrega anterior, sobre todo $A-3$, así como lo relativo a la primera parte de nuestro siglo en el número siguiente de esta revista].

5. Como decía atrás, 0 , me complace comprobar el gran interés por el conocimiento sistemático del pensamiento lingüístico del Renacimiento y, en general, por «épocas antiguas».Quiero llamar la atención, una vez más, sobre la importancia historiográfica del volumen de Juan M. Lope Blanch aqui aludido y, como dije, fichado en la entrega anterior, $A$-2.Le habría resultado especialmente útil al prof. Zamora Munné en el capítulo de su librito dedicado al Renacimiento. 


\section{Un trabajo de F. Abad}

0

Me refiero a «La variación lingüística», en Revista Española de Lingüística, 23-1/1993, págs. 73-86. Al igual que en el epígrafe anterior señalé la coincidencia de intereses historiográficos de mi investigación con respecto a la de otros estudiosos, aquí también me agrada comprobar algunos puntos de contacto. Los mencionaré...

1. En la entrega última, $A-4$, me fijé en la importancia de Rufino José Cuervo para todo lo relacionado con «arquitectura del lenguaje» (espacio, tiempo, nivel sociolingüístico y estilo). Aduje un expresivo texto epistolar entre el maestro hispánico y el gran Hugo Schuchardt. Pues bien: el apartado segundo del trabajo del prof. Abad se titula «Implantación de la Dialectología; Rufino José Cuervo», págs. 75-79. No se trata, claro está, de descubrir el océano con un autor sobre el que se ha publicado tanto y, sobre todo, después de los estudios de Guillermo L. Guitarte (el más importante de los cuales, al menos para mi propósito, quedaba mencionado al final del epígrafe que le dediqué al filólogo colombiano), sino de testimoniar la frescura doctrinal, la perennidad de los clásicos —entiéndase: auténticos- del estudio del lenguaje. De otro modo: cuando uno se acerca a Cuervo con ánimo de «no distraerse», vuelve uno siempre enriquecido y entusiasmado: continúa siendo un gran maestro, un maestro insigne.

2. El otro punto de coincidencia entre el prof. Abad y yo está en nuestro aprecio de la figura de Hugo Schuchardt (del que comencé a saber algo a través de los libros de Coseriu, sobre todo en aquello de que la gramática en el fondo es semántica: se habla para significar, etc.). Pues bien: en la nota 13 , pág. 76 , menciona nuestro estudioso hispano a Américo Castro (1924) y a Manuel Alvar (1969) como dos de las personas que mejor han sabido captar ideas fundamentales de Schuchardt sobre el concepto de mezcla, de mestizaje lingüístico; y sobre todo en el segundo investigador, con sus numerosos trabajos de geografía lingüística, de lingüística orientada hacia los hechos sociales, etc., tal idea adquiere un sentido de actualidad permanente. También A. Castro, con sus asedios sistemáticos a lo histórico de las manifestaciones hispánicas (incluidas las lingüísticas), nos resulta a los lectores de hoy un «hablante competente».

3. Bien: voy a citar, justamente, las palabras que Américo Castro escribió en 1924 ( LLingüistas del pasado y del presente», en Revista de Segunda Enseñanza [Madrid], segunda época, III-14/1925, págs. 271-277; también en su libro Lengua, enseñanza y literatura (esbozos), Victoriano Suárez, Madrid, 1924, págs. 140-170; se ocupa de Antonio de Nebrija y ...) sobre Hugo Schuchardt (págs. 274-275 en revista y 156-157 en libro): 
Hugo Schuchardt nació en 1842, y la mayor parte de sus ochenta años ha sido consagrada a la producción científica en el dominio de la filología románica y de la lingüística general. En 1866 publicó ya un trabajo de suma importancia: el $[E l]$ Vocalismo del latín vulgar, en tres volúmenes [Léipzig, 1866-1868: Der Vokalismus des Vulgärlateins]. Apenas se conocía entonces qué cosa fuese el latín hablado por el pueblo, fuente común de las distintas lenguas romances; portugués, español, italiano, etc. Nadie escribió nunca intencionadamente la lengua descuidada de la plebe; pero Schuchardt supo rastrear sus rasgos esenciales sirviéndose de las inscripciones, de los antiguos manuscritos, de las reglas o censuras de los gramáticos y de las palabras latinas incorporadas a idiomas extraños; de esa suerte quedaban sentadas las bases de la relación entre latín literario y latín hablado, y probada la uniformidad de la lengua que había de irse fragmentando en los distintos dialectos de la Romania.

En realidad, las palabras acabadas de citar son anteriores a la fecha atrás enunciada; no sin dificultad he podido rastrear su primera aparición: «Hugo Schuchardt», en Revista General [Madrid; quincenal], II-19/1918 (1 de septiembre), págs. 20-23 (20-21 el texto reproducido). El otro, «Antonio de Nebrija», en la misma revista, II-17/1918 (1 de agosto), págs. 22-25.

4. Aparecen referencias a otros autores (Saussure, Hockett, U. Weinreich, etc.) en el mencionado artículo de F. Abad, pero no me ocupo de ellas: me he limitado exclusivamente a dejarme acompañar científicamente en torno a autores de los que algo dije en la entrega anterior. Dejo aquí el recorrido por material complementario de lo ya presentado en «primera instancia».

\section{Galdós entre dos siglos}

Por supuesto, no se trata tampoco ahora de desarrollar las múltiples ideas de los estudiosos de Galdós en cuanto creador de lenguaje o de «pensamiento lingüístico», directamente o a través de sus personajes. La revista Anales Galdosianos, los varios congresos en torno a su persona y su obra, las abundantes publicaciones sobre aspectos varios - también lingüísticos, claro- de su universo creado, todo ello, digo, ahuyenta inmediatamente al más optimista ante el deseo de estudiar a fondo su obra desde el punto de vista linguiistico, específicamente en relación con lo que ocupa nuestra atención: la «arquitectura del lenguaje» (una vez más, espacio, tiempo, nivel sociolingüístico y estilo). Los estudios textuales sobre la corrección de pruebas por Galdós (Yolanda Arencibia, 1987; etc.) nos instruyen diáfanamente sobre las repercusiones, en los ejes diastrático y diafásico, de los cambios operados por nuestro escritor «sobre la marcha literaria»). También Emma Martinell ha estudiado (1989) algunas ideas lingüísticas (relación entre pensamiento y lenguaje) en la obra del gran 
observador y recreador insular canario y peninsular madrileño. Ahora bien: en el trabajo aludido de esta última investigadora no aparece por parte alguna referencia a un intento, de quien esto escribe, de presentación de las ideas sobre el lenguaje, «metalingüístico» por lo tanto, en Galdós. Como sospecho que, por el lugar donde se publicó, no resulta conocido en su justa necesidad, me voy a permitir ficharlo aquí ( $y$, naturalmente, porque afecta directamente a las cuestiones que nos atañen). Se trata, como digo, de...

1. PoLo, José, Galdós y el lenguaje, caps.XIV-Xv de «El español familiar y zonas afines (ensayo bibliográfico)», en Yelmo [Madrid], 1-1971/28-1976 (duró cinco años: entregas sucesivas). En el número 8,1972 , el apartado 6 está dedicado a nuestro escritor (bibliografía de trabajos lingüísticos: fichas 872-920); y ya desde el 9/1972-3 hasta el 16, 1974, me ocupo de presentar el mundo de las ideas lingüísticas en Galdós y en sus personajes. Voy a enumerar los diversos epígrafes que recorren este conjunto de ocho números sucesivos dedicados íntegramente a presentar textos de Galdós representativos de determinados modos de pensamiento lingüístico: 1. Afasia (fichas 964-971); 2. Lenguaje infantil (972-977); 3. Lenguas en contacto (978-990); 4. Diatopía (991-997); el 5, Diafasíaldiastratía, tras la introducción (998), se subdivide en los siguientes apartados: 5.1. Personas y caracterización lingüística (idiolectos) (999-1042); 5.2. De la burocracia a la retórica (1043-1063); 5.3. Etimología popular («culta»e «inculta») (1064-1096); 5.5.El pueblo (estrato inculto y «económicamente débil»)(1097-1118);5.6. Niveles sociolingüísticos y estilos (del pueblo a la aristocracia; del estilo familiar al "formal») (1119-1144); 6. Gramática normativa (en sentido lato) (1145-1157); 7.Lo coloquial (1158-1163); 8. «Lenguajes» diversos (1164-1166); 9. Final sobre Galdós (1167-1168).

2. Quien haga el recorrido «fraseográfico» completo en los materiales acabados de mencionar podrá observar la enorme riqueza de ideas, explícitas e implícitas, en la obra de nuestro escritor, en torno a lo que hoy día llamamos, siguiendo fundamentalmente a Coseriu, «los ejes diastrático y diafásico». Aunque mi trabajo era solo una muestra representativa de lo mucho que Galdós da de sí en tal perspectiva metalinguística, ya se ve cuánto podría salir puestos a trabajar a fondo en esta línea. A veces se hacen las cosas con carácter provisional, con el sano pensamiento de ampliarlas o fijarlas posteriormente: tal me ocurrió con toda la serie bibliográfica coloquial. No sé si las circunstancias me permitirán, al menos, completar lo relacionado con Galdós, pero, en todo caso, si hubiera alguna editorial interesada, recuperaria siquiera lo publicado entre 1972 y 1974 (ampliándolo algo y, claro está, revisándolo). Sea lo que fuere de la anterior sugerencia, lo importante es que se vea la importancia, para la idea de «arquitectura del lenguaje», de Galdós, protagonista, sin duda, dentro de lo que podría denominarse «Historia literaria de 
las ideas sobre el lenguaje» o quizá, igualmente, «Las fuentes literarias como material para la historia de la lingüística», esto es: «Los escritores y sus personajes: fuentes para el conocimiento, ilustrado, de las ideas sobre el lenguaje».

(continuará) 